\title{
JPEB
}

Jurnal Penelitian Ekonomi dan Bisnis, 2 (2), 2017, Hal : 101 - 113

http://www.jpeb.dinus.ac.id

\section{PENGARUH KUALITAS PRODUK DAN PERSEPSI HARGA TERHADAP KEPUASAN NASABAH MELALUI KEPERCAYAAN NASABAH ASURANSI JIWASRAYA CABANG KUDUS}

\author{
Vernando Satria Wijaya $^{1 *}$ dan Yohan Wismantoro ${ }^{2}$ \\ Magister Manajemen, Fakultas Ekonomi dan Bisnis ,Universitas Dian Nuswantoro \\ Jalan Imam Bonjol Semarang 50131, Indonesia \\ *Corresponding Author: vernandosw@gmail.com
}

Diterima: Mei 2017; Direvisi: Juli 2017; Dipublikasikan: September 2017

\begin{abstract}
The aims of this study was to examine and analyze the influence of Quality Product and Price Perceptions to PT. Asuransi Jiwasraya in Kudus. The method of collecting data using questionnaire and analysis techniques used Structural Equation Modeling to the 203 respondents. Analysis of the data in this study using AMOS version 22. The sampling technique used is purposive sampling and testing techniques of data used in this study include the validity and test reliability. The results showed that the variable quality product and price perceptions were positive and significant on the trust and customer satisfaction.
\end{abstract}

Keyword : Quality Product; Price Perceptions; Trust; Customer Satisfaction

\section{ABSTRAK}

Tujuan dari penelitian ini adalah untuk menguji dan menganalisis pengaruh Kualitas Produk dan Persepsi Harga terhadap PT. Asuransi Jiwasraya di Kudus. Metode pengumpulan data menggunakan kuesioner dan teknik analisis menggunakan Structural Equation Modeling kepada 203 responden. Analisis data dalam penelitian ini menggunakan AMOS versi 22. Teknik pengambilan sampel yang digunakan adalah purposive sampling dan teknik pengujian data yang digunakan dalam penelitian ini meliputi validitas dan uji reliabilitas. Hasil penelitian menunjukkan bahwa variabel kualitas produk dan persepsi harga adalah positif dan signifikan terhadap kepercayaan dan kepuasan pelanggan.

Kata Kunci: Produk Berkualitas; Persepsi Harga; Kepercayaan; Kepuasan Pelanggan 


\section{PENDAHULUAN}

Asuransi merupakan perjanjian antara dua pihak atau lebih, di mana pihak penanggung mengikatkan diri kepada tertanggung, dengan menerima premi asuransi, untuk memberikan penggantian kepada tertanggung karena kerugian, kerusakan atau kehilangan keuntungan yang diharapkan atau tanggung jawab hukum pihak ke tiga yang mungkin akan diderita tertanggung, yang timbul dari suatu peristiwa yang tidak pasti, atau memberikan suatu pembayaran yang didasarkan atas meninggal atau hidupnya seseorang yang dipertanggungkan (Undang-Undang No. 2 Th 1992). Badan yang menyalurkan risiko disebut "tertanggung", dan badan yang menerima risiko disebut "penanggung". Perjanjian antara kedua badan ini disebut kebijakan. Biaya yang dibayar oleh "tertanggung" kepada "penanggung" untuk risiko yang ditanggung disebut "premi". Ini biasanya ditentukan oleh "penanggung" untuk dana yang bisa diklaim pada masa depan, biaya administratif, dan keuntungan.

Saat ini banyak orang yang menjadi nasabah asuransi, karena terdapat beberapa keuntungan diantaranya, mengantisipasi musibah yang datangnya tidak terduga, sehingga berpengaruh terhadap harta bahkan jiwanya, biaya kesehatan yang terus meningkat (walaupun ada BPJS, namun terdapat beberapa obat atau pemeriksaan yang tidak dapat diganti oleh BPJS), risiko kematian yang datangnya tiba-tiba. Alasan lainnya oang pasti akan tua, sehingga kemampuan untuk mencari penghasilan atau bekerja akan menurun seiring dengan bertambahnya usia. Ada saatnya nanti tidak mampu lagi bekerja dan memperoleh penghasilan. Di situlah membutuhkan suatu jaminan finansial. Dengan menyadari bahwa asuransi itu penting serta memiliki perlindungan asuransi jiwa, biaya hidup dapat tetap di topang dan kehidupan serta kondisi keuangan pun akan memperoleh jaminan (Admin,2015).

Saat ini terdapat beberapa peruusahaan asuransi jiwa, seperti Adisarana Wanaartha, AXA Life, Bakrie Life, Bumi Asih Jaya, Bumiputera 1912, Central Asia Raya, Generali Indonesia, Asuransi Jiwamu, MNC Life Assurance dan Asuransi Jiwasraya. Dari beberapa perusahaan asuransi jiwa, yang paling tua adalah PT. Asuransi Jiwasraya. PT. Asuransi Jiwasraya adalah Badan Usaha Milik Negara Indonesia yang bergerak di sektor asuransi. PT.Asuransi Jiwasraya terlahir dengan gagasan mulia: mendidik masyarakat merencanakan masa depan. Sebuah gagasan besar yang telah lebih dari 152 tahun lalu disadari makna pentingnya oleh para perintis, pendiri dan penentu kebijakan di Republik ini. Untuk mengemban tugas mulia ini, PT. Asuransi Jiwasraya mengerahkan seluruh dedikasi dan keahliannya untuk memenuhi tuntutan kebutuhan masyarakat akan asuransi jiwa dan perencanaan keuangan yang semakin kompleks dan kompetitif.

PT. Asuransi Jiwasraya memiliki produk unggulan, yaitu anuitas, investasi, pendidikan dan proteksi. Jenis program jiwasraya lainnya adalah proteksi, saving dan purna tugas, tidak hanya itu jiwasrya juga menawarkan program unggulannya yaitu DPLK yang terdiri dari jiwasrya pesona DLPK dan Program Pensiunan Iuran Pasti atau yang disebut juga sebagai (PPIP). Jiwasraya juga menyediakan program asuransi diantaranya jaminan hari tua, tunjangan hari tua dan anuitas.

Obyek penelitian ini adalah PT. Asuransi Jiwasraya, J1. Pramuka No. 20, Mlati Kidul, Kota Kudus, Kabupaten Kudus, karena sebagian besar masyarakatnya sudah mengenal PT. Asuransi Jiwasraya dibandingkan asuransi perusahaan lain. Oleh karena itu, dengan mempromosikan produk asuransi PT. Asuransi Jiwasraya melalui agen di lapangan, diharapkan sebagian besar masyarakatnya tertarik untuk menjadi nasabah PT. Asuransi Jiwasraya. Semakin banyak masyarakat yang menjadi nasabah PT. Asuransi Jiwasraya menunjukkan bahwa nasabah puas pada asuransi yang bersangkutan.

Mengingat kualitas produk dan persepsi harga mempengaruhi kepuasan nasabah melalui kepercayaan, maka dirasa perlu untuk dilakukan penelitian dengan judul "Pengaruh Kualitas Produk dan Persepsi Harga Terhadap Kepuasan Nasabah Melalui Kepercayaan Nasabah Asuransi Jiwasraya Cabang Kudus”. 
Vernando Satria Wijaya dan Yohan Wismantoro : Pengaruh Kualitas Produk Dan Persepsi Harga Terhadap Kepuasan Nasabah Melalui Kepercayaan Nasabah Asuransi Jiwasraya Cabang Kudus

\section{TINJAUAN PUSTAKA \\ Kualitas Produk}

Menurut Kotler dan Keller (2009 : 4) produk adalah segala sesuatu yang dapat ditawarkan kepada pasar untuk memuaskan suatu keinginan atau kebutuhan, termasuk barang fisik, jasa, pengalaman, acara, orang, tempat, property, organisasi, infomasi, dan ide. Kemudian menurut Kotler dan Amstrong (2007 : 347) kualitas produk adalah kemampuan suatu produk untuk melakukan gungsi-fungsinya, kemampuan itu meliBauran pemasaran jasa adalah perencanaan dan pelaksanaan terkoordinasi kegiatan-kegiatan pemasaran, operasi, dan sumber daya manusia yang penting bagi keberhasilan perusahaan jasa (Lovelock dan Wright,2007 : 18). Produk adalah sesuatu yang ditawarkan oleh perusahaan kepada nasabah guna memenuhi kebutuhan dan memuaskan nasabah (Cannon dkk, 2008 : 285). Definisi lain produk adalah produk adalah semua hal yang dapat ditawarkan kepada pasar untuk menarik perhatian, akuisisi, penggunaan, atau konsumsi yang dapat memuaskan suatu keinginan atau kebutuhan (Kotler dan Amstrong, 2008 : 266). Menurut Laksana (2008 : 67), produk adalah segala sesuatu baik yang bersifat fisik maupun non fisik yang dapat ditawarkan kepada nasabah untuk memenuhi segala keinginan dan kebutuhannya. Sedangkan Kotler dan Keller (2009 : 4) mendefinisikan produk adalah sesuatu yang dapat ditawarkan kepada pasar untuk memuaskan suatu keinginan atau kebutuhan, termasuk barang fisik, jasa, pengalaman, acara, orang, tempat, properti, organisasi, informasi dan ide. Menurut Daryanto (2013 : 52), produk adalah segala sesuatu yang dapat ditawarkan ke pasar untuk mendapatkan perhatian, dibeli, dipergunakan atau dikonsumsi dan yang dapat memuaskan keinginan atau kebutuhan.

\section{Persepsi Harga}

Bunga adalah segala sesuatu yang diberikan oleh nasabah untuk mendapatkan keunggulan yang ditawarkan oleh bauran pemasaran perusahaan (Cannon, dkk, 2008 : 176). Pengertian lain bunga adalah sejumlah uang yang ditagihkan atas sesuatu produk atau jasa atau jumlah dari nilai yang ditukarkan para nasabah untuk memperoleh manfaat dari memiliki atau menggunakan suatu produk atau jasa (Kotler dan Amstrong,2008:345). Menurut Laksana (2008 : 105), bunga adalah jumlah uang yang diperlukan sebagai penukar berbagai kombinasi produk dan jasa. Juga menurut Tjiptono (2008 : 151), bunga adalah satuan moneter atau ukuran lainnya (termasuk barang dan jasa lainnya) yang ditukarkan agar memperoleh hak kepemilikan atau penggunaan suatu barang atau jasa. Sedangkan menurut Kotler dan Keller (2009 : 67), bunga adalah nilai uang untuk menghasilkan pendapatan dan biaya. Daryanto (2013 : 62) mendefinisikan bunga jumlah uang yang ditagihkan untuk suatu produk atau sejumlah nilai yang dipertukarkan nasabah untuk manfaat memiliki atau menggunakan produk. Bunga bisa diungkapkan dengan berbagai istilah, misalnya iuran, tarif sewa, bunga, premium, komisi, upah, gaji, horarium dan sebagainya. Tingkat bunga yang ditetapkan mempengaruhi kuantitas yang terjual. Selain itu, secara tidak langsung bunga juga mempengaruhi biaya, karena kuantitas yang terjual berpengaruh pada biaya yang ditimbulkan dalam kaitannya dengan efisiensi produksi. Oleh karena penetapan bunga mempengaruhi pendapatan total dan biaya total, maka keputusan dan strategi penetapan bunga memegang peranan penting dalam setiap perusahaan. Sementara itu dari sudut pandang nasabah, bunga seringkali digunakan sebagai indikator nilai bilamana bunga tersebut dihubungkan dengan manfaat yang dirasakan atas suatu barang atau jasa (Tjiptono, $2008: 151$ ).

Pada tingkat bunga tertentu, bila manfaat yang dirasakan nasabah meningkat, maka nilainya akan meningkat pula. Demikian pula sebaliknya, pada tingkat bunga tertentu, nilai suatu barang atau jasa akan meningkat seiring dengan meningkatnya manfaat yang dirasakan. Seringkali pula dalam penentuan nilai suatu barang atau jasa, nasabah membandingkan kemampuan suatu barang atau jasa dalam memenuhi kebutuhannya dengan kemampuan barang atau jasa substitusi (Tjiptono, $2008: 152$ ). 


\section{Kepercayaan}

Morgan dan Hunt (Ananto, 2012) mendefinisikan kepercayaan pelanggan adalah suatu rasa percaya kepada mitra dimana seseorang berhubungan. Sementara itu Indarjo (2011) mendefinisikan kepercayaan pelanggan sebagai suatu kerelaan untuk bergantung kepada partner dalam suatu hubungan transaksi dimana dalam diri partner itulah diletakkan keyakinan. Kepercayaan pelanggan timbul dari suatu proses yang lama. Apabila Kepercayaan Pelanggan sudah timbul antara pelanggan dan perusahaan, maka usaha untuk membina hubungan kerjasama kaan lebih mudah. Kepercayaan pelanggan timbul ditunjukkan oleh suatu kredibilitas yang diperoleh dari pihak lain karena memiliki keahlian yang dikehendaki untuk melakukan suatu tugas, kepercayaan pelanggan juga dapat diperoleh karena melakukan sesuatu hal yang terbaik kepada pihak lain melalui suatu hubungan. (Hermawan, 2011) Tingkat kepercayaan pelanggan dapat diukur melalui beberapa faktor antara lain kejujuran dalam bertransaksi, tanggung jawab perusahaan terhadap pelanggan, dan masih banyak lagi. Kepercayaan pelanggan adalah apabila salah satu pihak mempunyai keyakinan dalam keandalan dan integritas partner kerjasama. Suatu hubungan baik terbina pada seseorang mengalami hal yang menarik, atau spesifiik dan keunikan serta kualitas pelayanan yang diberikan selanjutnya tetap dipertahankan, bahkan selalu ditingkatkan. Jadi yang dirasakan oleh pemakai jasa bukan hanya pengalaman sesaat, tetapi sebagai suatu peningkatan kepecayaan pelanggan dari pengalaman terdahulu untuk dilanjutkan pada masa yang akan datang (Jasfar, 2012). Kepercayaan pelanggan adalah perekat yang memungkinkan perusahaan untuk mempercayai orang lain dalam mengorganisir dan menggunakan sumber daya secara efektif. Kepercayaan pelanggan yang terbina, termasuk untuk mempercayai seseorang akan menimbulkan kepercayaan pelanggan yang tinggi serta akan kemampuan dan keinginannya.

\section{Kepuasan Pelanggan}

Kepuasan konsumen adalah reaksi emosional jangka pendek konsumen terhadap kinerja jasa tertentu (Lovelock dan Wright, 2007 : 96). Konsep lain kepuasan konsumen adalah perasaan senang atau kecewa seseorang yang muncul setelah membandingkan antara kinerja (hasil) produk yang dipikirkan terhadap kinerja yang diharapkan (Kotler dan Keller, 2009 : 138).

Konsumen mengalami berbagai tingkat kepuasan atau ketidakpuasan setelah mengalami masing-masing jasa sesuai dengan sejauh mana harapan konsumen terpenuhi atau terlampaui. Hal ini karena kepuasan adalah keadaan emosional, reaksi pasca-pembelian konsumen dapat berupa kemarahan, ketidakpuasan, kejengkelan, netralitas, kegembiraan, atau kesenangan. Konsumen yang marah atau tidak puas akan menimbulkan masalah karena dapat berpindah ke perusahaan lain dan menyebarkan berita negatif dari mulut ke mulut (Lovelock dan Wright, 2007 : 102).

Puas tidaknya konsumen diketahui setelah melakukan pembelian, tergantung pada kinerja tawaran dalam pemenuhan harapan pembeli. Jika kinerja berada di bawah harapan, konsumen tidak puas. Jika kinerja memenuhi harapan, konsumen puas. Jika kinerja melebihi harapan, konsumen amat puas atau senang (Kotler dan Keller, 2009 : 139).

Walaupun perusahaan yang berpusat pada konsumen berupaya untuk menciptakan kepuasan konsumen yang tinggi dengan menurunkan harganya atau meningkatkan jasanya, kemungkinan hasilnya adalah laba yang lebih rendah. Perusahaan mungkin mampu meningkatkan profitabilitasnya dengan sarana lain daripada meningkatkan kepuasan. Perusahaan memiliki banyak pihak berkepentingan, termasuk karyawan, penyalur, pemasok, dan pemegang saham. Perusahaan mengeluarkan lebih banyak biaya bertujuan untuk meningkatkan kepuasan konsumen (Kotler dan Keller, 2009 : 139). 


\section{Kerangka Pemikiran}

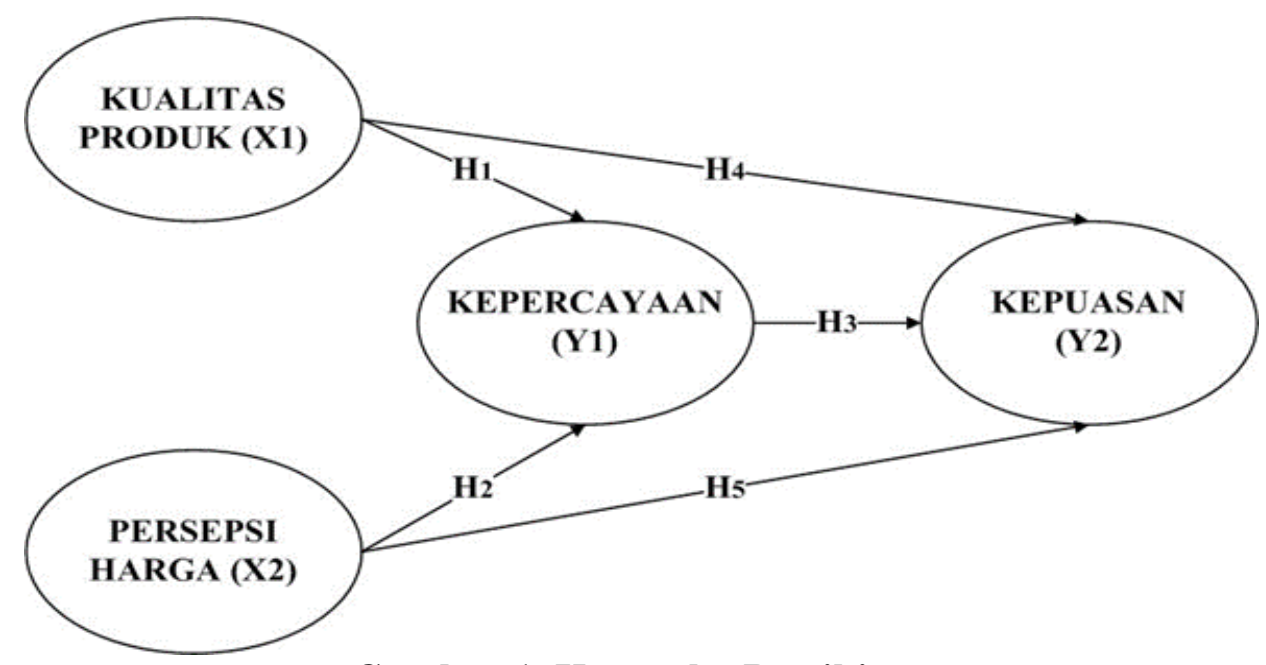

Gambar 1. Kerangka Pemikiran

\section{Hipotesis}

Secara umum kerangka pikir yang digunakan dalam penelitian ini dapat dilihat pada gambar 1.

$\mathrm{H}_{1}$ : kualitas produk berpengaruh positif terhadap kepercayaan.

$\mathrm{H}_{2}$ : persepsi harga berpengaruh positif terhadap kepercayaan.

$\mathrm{H}_{3}$ : kualitas produk berpengaruh positif terhadap kepuasan pelanggan.

$\mathrm{H}_{4}$ : persepsi harga berpengaruh positif terhadap kepuasan pelanggan.

$\mathrm{H}_{5}$ : kepercayaan berpengaruh positif terhadap kepuasan pelanggan.

\section{METODE PENELITIAN}

\section{Variabel Penelitian}

Variabel endogen dalam penelitian ini adalah Kepercayaan $\left(\mathrm{Y}_{1}\right)$ dan Kepuasan Pelanggan $\left(\mathrm{Y}_{2}\right)$ dari pelanggan Jiwasraya cabang kudus.

Variabel eksogen dalam penelitian ini adalah kualitas produk $\left(\mathrm{X}_{1}\right)$ dan persepsi harga $\left(\mathrm{X}_{2}\right)$ dari pelanggan Jiwasraya cabang kudus.

\section{Definisi Operasional}

Tabel 1 adalah definisi operasional untuk tiap variabel dan indikator.

Tabel 1. Definisi Operasional Variabel

\begin{tabular}{|c|c|c|}
\hline Variabel & Definisi Operasional & Indikator \\
\hline $\begin{array}{c}\text { Kualitas } \\
\text { Produk }\left(\mathbf{X}_{1}\right)\end{array}$ & $\begin{array}{l}\text { Keseluruhan ciri serta sifat } \\
\text { barang dan jasa yang } \\
\text { berpengaruh pada } \\
\text { kemampuan memenuhi } \\
\text { kebutuhan yang } \\
\text { dinyatakan maupun yang } \\
\text { tersirat (Kotler, 2009) }\end{array}$ & $\begin{array}{l}\text { 1. Premi asuransi jiwasraya sesuai } \\
\text { dengan harapan konsumen } \\
\text { 2. Produk asuransi jiwasraya } \\
\text { berkualitas } \\
\text { 3. Produk asuransi jiwasraya } \\
\text { memberikan kemudahan bagi } \\
\text { konsumen } \\
\text { 4. Memudahkan nasabah dengan } \\
\text { membayar premi sesuai } \\
\text { kebutuhannya (Pradhana, 2015) Saya } \\
\text { akan menyesal apabila beralih ke } \\
\text { produk kecantikan merek lain tidak }\end{array}$ \\
\hline
\end{tabular}




\begin{tabular}{|c|c|c|}
\hline $\begin{array}{c}\text { Persepsi } \\
\text { Harga }\left(X_{2}\right)\end{array}$ & $\begin{array}{l}\text { Sejumlah uang yang } \\
\text { ditukarkan untuk sebuah } \\
\text { produk atau jasa (Yusup, } \\
\text { 2011) }\end{array}$ & $\begin{array}{l}\text { cocok dengan wajah saya. } \\
\text { 1. Harga premi terjangkau } \\
\text { 2. Harga premi sesuai dengan kualitas } \\
\text { 3. Harga premi dapat bersaing } \\
\text { 4. Harga premi sesuai dengan manfaat } \\
\text { yang didapat (Yusup, 2011) }\end{array}$ \\
\hline $\begin{array}{c}\text { Kepercayaan } \\
\text { (Y1) }\end{array}$ & $\begin{array}{l}\text { Kepercayaan adalah } \\
\text { keyakinan seseorang } \\
\text { terhadap nilai-nilai tertentu } \\
\text { yang akan mempengaruhi } \\
\text { perilakunya (Peter dan } \\
\text { Olson, 2013: 136). }\end{array}$ & $\begin{array}{l}\text { 1. Percaya pada produk jasa asuransi } \\
\text { jiwasraya } \\
\text { 2. Percaya pada perusahaan asuransi } \\
\text { jiwasraya } \\
\text { 3. Percaya pada sistem asuransi } \\
\text { jiwasraya } \\
\text { 4. percaya bahwa asuransi jiwasraya } \\
\text { tidak akan menipu nasabahnya } \\
\text { 5. Asuransi jiwasraya dapat dipercaya } \\
\text { karena sangat memperhatikan } \\
\text { kebutuhan nasabahnya (Zamroni, } \\
\text { 2009) }\end{array}$ \\
\hline $\begin{array}{l}\text { Kepuasan } \\
\text { Pelanggan } \\
\quad(\text { Y2) }\end{array}$ & $\begin{array}{l}\text { Kepuasan konsumen } \\
\text { adalah perasaan senang } \\
\text { atau kecewa seseorang } \\
\text { yang muncul setelah } \\
\text { membandingkan antara } \\
\text { kinerja (hasil) produk yang } \\
\text { dipikirkan terhadap kinerja } \\
\text { yang diharapkan (Kotler } \\
\text { dan Keller, 2009: 138) }\end{array}$ & $\begin{array}{l}\text { 1. Puas dengan kinerja / kemampuan } \\
\text { sesuai harapan nasabah } \\
\text { 2. Kepuasan informasi yang diberikan } \\
\text { dari karyawan } \\
\text { 3. Kepuasan atas sikap hormat dan } \\
\text { menghargai nasabah } \\
\text { 4. Kepuasan pada teknologi yang } \\
\text { digunakan (Harnoto, 2013) }\end{array}$ \\
\hline
\end{tabular}

\section{Populasi dan Sampel}

Populasi pada penelitian ini adalah member dari Klinik Estetika Semarang. Untuk mengukur sample berdasarkan rumus Slovin maka diperoleh sampel sebanyak 203,6 sehingga dibulatkan menjadi 203 sampel.

\section{Teknik Pengambilan Sampel}

Teknik pengambilan sampel yang digunakan adalah Purposive Sampling dengan karakteristik untuk pengambilan sampel yaitu responden yang sudah pernah datang ke Klinik Estetika selama 3 kali

\section{HASIL DAN PEMBAHASAN \\ Uji Validitas}

Uji validitas digunakan untuk mengukur valid atau tidaknya suatu kuesioner. Suatu kuesioner dikatakan valid apabila pertanyaan dalam kuesioner mampu mengungkapkan sesuatu melalui pengukuran. Uji validitas dapat dilakukan melalui konstruk (CFA) maupun konvergen. Untuk hasil pengujian validitas konstruk disajikan sebagai berikut: 
Tabel 2. Uji Validitas

\begin{tabular}{|c|c|c|c|c|c|c|c|}
\hline & & & Estimate & S.E. & C.R. & $\mathbf{P}$ & Label \\
\hline $\mathbf{x 1 1}$ & $<--$ & $\overline{X 1}$ & 1,000 & & & & \\
\hline $\mathbf{x 1 2}$ & $<---$ & $\mathrm{X} 1$ & 1,042 &, 051 & 20,625 & $* * *$ & \\
\hline $\mathbf{x} 13$ & $<---$ & $\mathrm{X} 1$ & 1,042 &, 051 & 20,457 & $* * *$ & \\
\hline x14 & $<---$ & $\mathrm{X} 1$ & 1,023 & 053 & 19,471 & $* * *$ & \\
\hline x 24 & $<---$ & $\mathrm{X} 2$ & 1,000 & & & & \\
\hline $\mathbf{x} 23$ & $<---$ & $\mathrm{X} 2$ & 1,014 & ,061 & 16,582 & $* * *$ & \\
\hline $\mathbf{x} 22$ & $<---$ & $\mathrm{X} 2$ & 1,081 & ,060 & 18,155 & $* * *$ & \\
\hline $\mathbf{x} 21$ & $<---$ & $\mathrm{X} 2$ & 1,052 & ,060 & 17,583 & $* * *$ & \\
\hline y1 & $<---$ & $\mathrm{Y}$ & 1,000 & & & & \\
\hline y2 & $<---$ & $\mathrm{Y}$ & 1,018 & ,060 & 16,988 & $* * *$ & \\
\hline y3 & $<--$ & $Y$ & 1,124 & ,058 & 19,397 & $* * *$ & \\
\hline y4 & $<---$ & Y & 1,050 & ,056 & 18,865 & $* * *$ & \\
\hline i5 & $<---$ & I & 1,000 & & & & \\
\hline i4 & $<---$ & I & ,996 & 054 & 18,337 & $* * *$ & \\
\hline i3 & $<--$ & I & ,994 & 053 & 18,758 & $* * *$ & \\
\hline i2 & $<---$ & I & 1,081 & ,058 & 18,745 & $* * *$ & \\
\hline i1 & $<---$ & I & 1,025 &, 054 & 19,063 & $* * *$ & \\
\hline
\end{tabular}

Validitas konstruk dimaksudkan untuk mengukur apakah konstruk (indikator) mampu atau tidak merefleksikan variabel latennya. Hasilnya memenuhi kriteria yaitu nilai critical ratio (C.R) $>1,96$ dengan probability $(\mathrm{P})<0,05$. Berdasarkan tabel 2 menunjukkan bahwa semua indikator menghasilkan nilai estimasi dengan critical error $(\mathrm{C} . \mathrm{R})>1,96$ dan nilai probability $(\mathrm{P})$ $<0,05$. Untuk itu dapat disimpulkan bahwa indikator-indikator yang digunakan adalah valid.

\section{Uji Reliabilitas}

Uji reliabilitas digunakan untuk melihat konsistensi indikator apabila digunakan untuk mengukur suatu variabel yang sama. Dalam hal ini uji reliabilitas dilakukan dengan menggunakan dua cara yaitu construct reliability dan variance extracted. Tabel 3 memperlihatkan hasi uji reliabilitas.

Tabel 3. Uji Reliability dan Variance Extracted

\begin{tabular}{ccccccc}
\hline Variabel & Indikator & $\begin{array}{c}\text { Standar } \\
\text { Loading }\end{array}$ & $\begin{array}{c}\text { Standar }_{\text {Loading }^{2}} \\
\mathbf{X}_{\mathbf{1}}\end{array}$ & $\begin{array}{c}\text { 1 - Standar } \\
\text { Loading }^{2}\end{array}$ & $\begin{array}{c}\text { Construct } \\
\text { Reliability }\end{array}$ & $\begin{array}{c}\text { Variance } \\
\text { Extracted }\end{array}$ \\
& X11 & 0,901 & 0,812 & 0,188 & 0,948 & 0,819 \\
& X12 & 0,914 & 0,835 & 0,165 & & \\
& X13 & 0,911 & 0,830 & 0,170 & & \\
& X14 & 0,893 & 0,797 & 0,203 & & \\
$\mathbf{X}_{\mathbf{2}}$ & TOTAL & 3,619 & 3,275 & 0,725 & & \\
& X21 & 0,878 & 0,771 & 0,229 & 0,930 & 0,770 \\
& X22 & 0,892 & 0,796 & 0,204 & & \\
& X23 & 0,852 & 0,726 & 0,274 & & \\
& X24 & 0,887 & 0,787 & 0,213 & & \\
& TOTAL & 3,509 & 3,079 & 0,921 & & \\
& I1 & 0,901 & 0,812 & 0,188 & 0,951 & 0,795 \\
\hline
\end{tabular}




\begin{tabular}{lccllll}
\hline & I3 & 0,895 & 0,801 & 0,199 & & \\
& I4 & 0,885 & 0,783 & 0,217 & & \\
& I5 & 0,884 & 0,781 & 0,219 & & \\
Y & TOTAL & 4,459 & 3,977 & 1,023 & & \\
& Y1 & 0,873 & 0,762 & 0,238 & 0,941 & \\
& Y2 & 0,867 & 0,752 & 0,248 & & \\
& Y3 & 0,925 & 0,856 & 0,144 & \\
& Y4 & 0,913 & 0,834 & 0,166 & \\
\\
TOTAL & 3,578 & 3,203 & 0,797 & & \\
\hline
\end{tabular}

Berdasarkan tabel 3 dapat diketahui bahwa nilai reliabilitas konstruk berada diatas 0,70 yang berarti instrument reliabel dan nilai variance extracted di atas 0,50 yang menunjukkan indikator-indikator yang digunakan sebagai observed variabel relatif mampu menjelaskan variabel laten yang dibentuknya.

\section{Hasil Analisis SEM}

Hasil analisis SEM, dapat dilihat pada gambar 2 berikut ini.

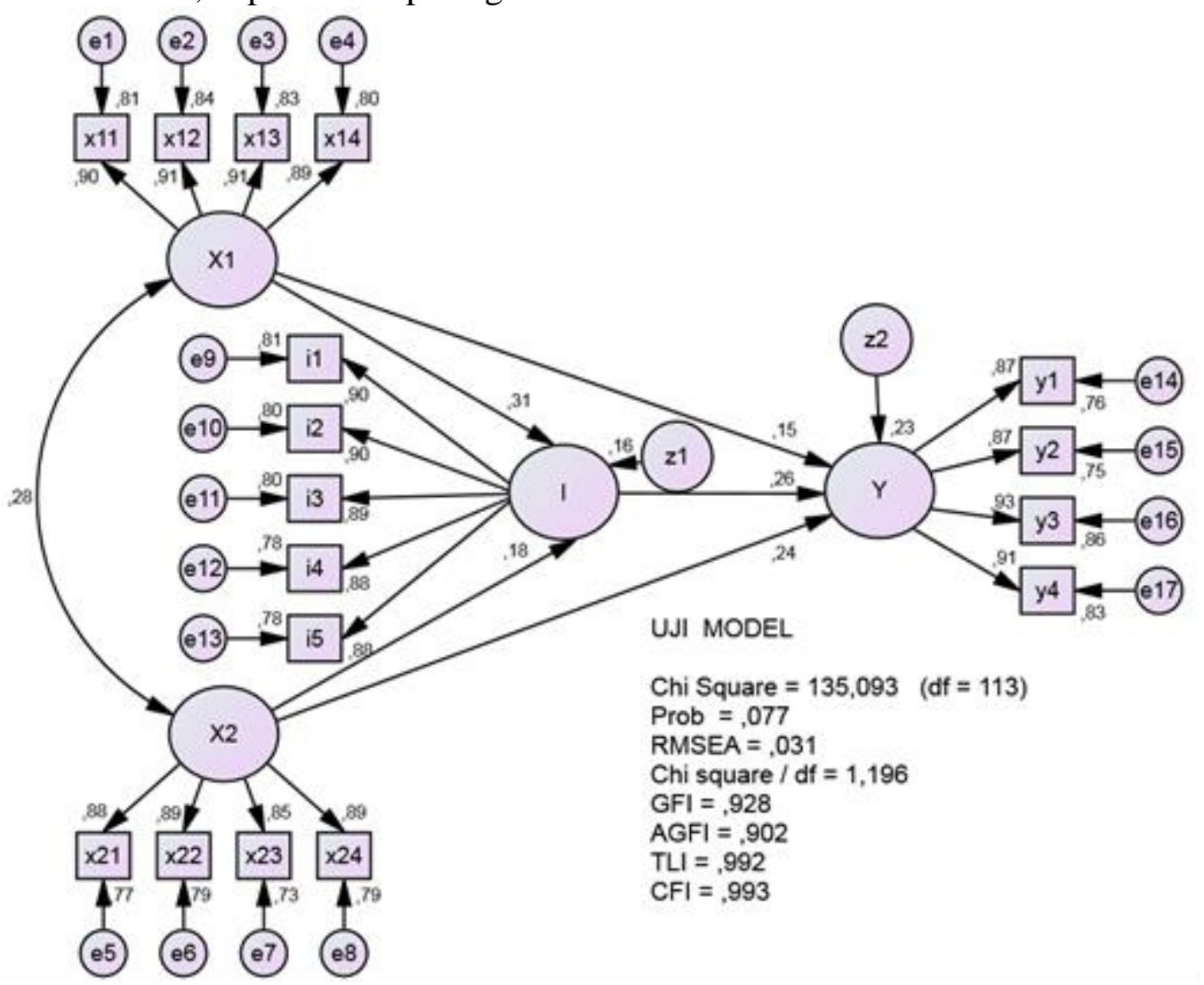

Gambar 2. Hasil SEM

\section{Pengujian Hipotesis}

Pengujian terhadap hipotesis yang diajukan dapat dilakukan berdasarkan dari nilai critical ratio (CR) dan tingkat prob. yang terdapat pada regression weight, dimana diperlukan nilai $\mathrm{CR} \geq 2,00$ dan prob. $\leq \alpha=0,05$ sebagai syarat penerimaan hipotesis. Hasil nilai $\mathrm{CR}$ dan tingkat probabilitas antar variabel yang dihipotesiskan dapat dilihat hasilnya seperti pada tabel 4 
Vernando Satria Wijaya dan Yohan Wismantoro : Pengaruh Kualitas Produk Dan Persepsi Harga Terhadap Kepuasan Nasabah Melalui Kepercayaan Nasabah Asuransi Jiwasraya Cabang Kudus

Tabel 4. Nilai CR dan Tingkat Probabilitas

\begin{tabular}{|c|c|c|c|c|c|c|c|}
\hline & & & Estimate & S.E. & C.R. & $\mathbf{P}$ & Label \\
\hline $\begin{array}{l}\text { Kepercayaan } \\
\text { (Intervening) }\end{array}$ & $\begin{array}{l}<-- \\
\end{array}$ & $\begin{array}{l}\text { Kualitas } \\
\text { Produk (X1) }\end{array}$ & 0.299 & 0.071 & 4.191 & $* * *$ & \\
\hline $\begin{array}{l}\text { Kepercayaan } \\
\text { (Intervening) }\end{array}$ & $<--$ & $\begin{array}{l}\text { Persepsi } \\
\text { Harga (X2) }\end{array}$ & 0.187 & 0.076 & 2.47 & 0.013 & \\
\hline $\begin{array}{l}\text { Kepuasan } \\
\text { (Y) }\end{array}$ & $<---$ & $\begin{array}{l}\text { Kepercayaan } \\
\text { (Intervening) }\end{array}$ & 0.261 & 0.073 & 3.553 & $* * *$ & \\
\hline $\begin{array}{l}\text { Kepuasan } \\
\text { (Y) }\end{array}$ & $<---$ & $\begin{array}{l}\text { Kualitas } \\
\text { Produk (X1) }\end{array}$ & 0.144 & 0.071 & 2.026 & 0.043 & \\
\hline $\begin{array}{l}\text { Kepuasan } \\
\text { (Y) }\end{array}$ & $<--$ & $\begin{array}{l}\text { Persepsi } \\
\text { Harga (X2) }\end{array}$ & 0.25 & 0.075 & 3.352 & $* * *$ & \\
\hline
\end{tabular}

Berdasarkan data dari hasil pengolahan data diketahui bahwa nilai C.R (Critical Ratio) sebesar 4,191 dengan nilai $\mathrm{P}$ (probability) sebesar 0,000. Kedua nilai ini menunjukkan hasil yang memenuhi syarat, yaitu di atas 1,96 untuk $C R$ dan dibawah 0,05 untuk nilai $P$ sehingga dapat disimpulkan bahwa $\mathrm{H}_{1}$ pada penelitian ini diterima. Hal ini menunjukkan bahwa kualitas produk mempengaruhi secara positif kepercayaan PT. Asuransi Jiwasraya .Nilai CR kepuasan pelanggan terhadap pembelian ulang sebesar 2,655 dengan prob. 0.008 . Nilai CR yang didapat lebih besar dari 2,00 dan nilai prob. juga lebih kecil dari 0,05. Berdasarkan dari hasil yang didapat ini maka menerima hipotesis yang menyatakan kepuasan pelanggan berpengaruh terhadap pembelian ulang.

Berdasarkan data dari hasil pengolahan data diketahui bahwa nilai C.R (Critical Ratio) sebesar 2,47 dengan nilai P (probability) sebesar 0,013. Kedua nilai ini menunjukkan hasil yang memenuhi syarat, yaitu di atas 1,96 untuk CR dan dibawah 0,05 untuk nilai $\mathrm{P}$ sehingga dapat disimpulkan bahwa $\mathrm{H}_{2}$ pada penelitian ini diterima. Hal ini menunjukkan bahwa Harga mempengaruhi secara positif Kepercayaan PT. Asuransi Jiwasraya ..

Berdasarkan data dari hasil pengolahan data diketahui bahwa nilai C.R (Critical Ratio) sebesar 2,026 dengan nilai P (probability) sebesar 0,043. Kedua nilai ini menunjukkan hasil yang memenuhi syarat, yaitu di atas 1,96 untuk CR dan dibawah 0,05 untuk nilai $\mathrm{P}$ sehingga dapat disimpulkan bahwa $\mathrm{H}_{3}$ pada penelitian ini diterima. Hal ini menunjukkan bahwa kualitas produk mempengaruhi secara positif kepuasan pelanggan PT. Asuransi Jiwasraya.

Berdasarkan data dari hasil pengolahan data diketahui bahwa nilai C.R (Critical Ratio) sebesar 3,352 dengan nilai $\mathrm{P}$ (probability) sebesar 0,000. Kedua nilai ini menunjukkan hasil yang memenuhi syarat, yaitu di atas 1,96 untuk CR dan dibawah 0,05 untuk nilai $\mathrm{P}$ sehingga dapat disimpulkan bahwa $\mathrm{H}_{4}$ pada penelitian ini diterima. Hal ini menunjukkan bahwa harga mempengaruhi secara positif kepuasan pelanggan PT. Asuransi Jiwasraya.

Berdasarkan data dari hasil pengolahan data diketahui bahwa nilai C.R (Critical Ratio) sebesar 3,553 dengan nilai $\mathrm{P}$ (probability) sebesar 0,000. Kedua nilai ini menunjukkan hasil yang memenuhi syarat, yaitu di atas 1,96 untuk $\mathrm{CR}$ dan dibawah 0,05 untuk nilai $\mathrm{P}$ sehingga dapat disimpulkan bahwa $\mathrm{H}_{5}$ pada penelitian ini diterima. Hal ini menunjukkan bahwa kepercayaan mempengaruhi secara positif kepuasan pelanggan PT. Asuransi Jiwasraya.

\section{Pembahasan}

Hasil penelitian dari pengaruh kualitas produk dan persepsi harga terhadap kepuasan nasabah melalui kepercayaan pelanggan Jiwasraya cabang kudus dapat dianalisa melalui pembahasan berikut: 


\section{Pengaruh Kualitas Produk terhadap Kepercayaan.}

Dari penelitian yang dilakukan menunjukkan bahwa menurut konsumen, kualitas produk yang ditunjukkan oleh PT. Asuransi Jiwasraya Kudus termasuk baik dengan nilai indeks yang tinggi (dengan nilai rata - rata 6,938). Dapat di artikan bahwa produk yang berkualitas dan sesuai dengan harapan konsumen akan mempengaruhi kepercayaan konsumen terhadap produk itu sendiri. Hal ini ditunjukkan oleh data yang diperoleh dari penelitian dengan rata - rata indeks 6,938 menunjukkan bahwa produk yang di berikan jiwasraya untuk memenuhi kebutuhan para nasabah sudah cukup sesuai dan berkualitas. Sehingga dari hasil questioner diperoleh nilai indeks yang masuk dalam kategori tinggi. Nilai tertinggi ditunjukkan pada indikator produk asuransi jiwasraya berkualitas $(7,586)$ yang berarti kualitas produk yang diberikan oleh asuransi jiwasraya sudah sesuai dengan harapan nasabah. Persepsi Kualitas Produk memberikan pengaruh yang positif terhadap Kepercayaan, maka jika persepsi Kualitas Produk meningkat maka Kepercayaan akan meningkat juga begitupula sebaliknya. Hasill penelitian ini didukung oleh penelitian Widjaja (2014) yang menunjukkan bahwa Kualitas Produk berpengaruh positif dan signifikan terhadap Kepercayaan.

\section{Pengaruh Harga terhadap Kepercayaan.}

Berdasarkan dari penelitian yang dilakukan menunjukkan bahwa menurut konsumen persepsi harga yang ditunjukkan oleh PT. Asuransi Jiwasraya kudus termasuk dengan kategori tinggi (dengan nilai rata - rata 6,698). Dapat di artikan bahwa persepsi harga yang sesuai dan bersaing akan mempengaruhi kepercayaan konsumen terhadap produk itu sendiri. Hal ini ditunjukkan oleh data yang diperoleh dari penelitian dengan rata - rata indeks 6,698 menunjukkan bahwa harga yang ditawarkan oleh jiwasraya sudah sesuai dengan persepsi konsumen terhadap harga produk jiwasraya, sehingga dari hasil quest diperoleh nilai indeks yang masuk dalam kategori tinggi. Nilai tertinggi ditunjukkan pada indikator harga premi sesuai dengan kualitas $(6,996)$ yang berarti harga yang dibayarkan nasabah dari produk asuransi jiwasraya sudah sesuai dengan kualitas yang didapatkan oleh nasabah. Persepsi Harga memberikan pengaruh yang positif terhadap Kepercayaan, maka jika persepsi Persepsi Harga meningkat maka Kepercayaan akan meningkat juga begitupula sebaliknya. Hasill penelitian yang dilakukan oleh Widjaja (2014) mendukung penelitian ini dengan menunjukkan bahwa Persepsi Harga berpengaruh positif dan signifikan terhadap Kepercayaan

\section{Pengaruh Kualitas Produk terhadap Kepuasan Pelanggan.}

Dari penelitian yang dilakukan menunjukkan bahwa menurut konsumen, kualitas produk yang ditunjukkan oleh PT. Asuransi Jiwasraya Kudus termasuk baik dengan nilai indeks yang tinggi (dengan nilai rata - rata 6,938). Dapat di artikan bahwa produk yang berkualitas dan sesuai dengan harapan konsumen akan meningkatkan kepuasan konsumen terhadap produk itu sendiri. Hal ini ditunjukkan oleh data yang diperoleh dari penelitian dengan rata - rata indeks 6,938 menunjukkan bahwa produk yang di berikan jiwasraya untuk memenuhi kebutuhan para nasabah sudah cukup sesuai dan berkualitas, sehingga dari hasil quest diperoleh nilai indeks yang masuk dalam kategori tinggi. Nilai tertinggi ditunjukkan pada indikator produk asuransi jiwasraya berkualitas $(7,586)$ yang berarti kualitas produk yang diberikan oleh asuransi jiwasraya sudah sesuai dengan harapan nasabah. Persepsi Kualitas Produk memberikan pengaruh yang positif terhadap Kepuasan Pelanggan, maka jika persepsi Kualitas Produk meningkat maka Kepuasan Pelanggan akan meningkat juga begitupula sebaliknya. Hasill penelitian yang dilakukan oleh Endarwita (2013) dan Gultom, dkk (2014) mendukung penelitian ini dengan menunjukkan bahwa Kualitas Produk berpengaruh positif dan signifikan terhadap Kepuasan Pelanggan. 
Vernando Satria Wijaya dan Yohan Wismantoro : Pengaruh Kualitas Produk Dan Persepsi Harga Terhadap Kepuasan Nasabah Melalui Kepercayaan Nasabah Asuransi Jiwasraya Cabang Kudus

\section{Pengaruh Harga terhadap Kepuasan Pelanggan.}

Berdasarkan dari penelitian yang dilakukan menunjukkan bahwa menurut konsumen persepsi harga yang ditunjukkan oleh PT. Asuransi Jiwasraya Kudus termasuk dengan kategori tinggi (dengan nilai rata - rata 6,698). Dapat di artikan bahwa persepsi harga yang sesuai dan bersaing akan mempengaruhi kepuasan pelanggan terhadap produk itu sendiri. Hal ini ditunjukkan oleh data yang diperoleh dari penelitian dengan rata - rata indeks 6,698 menunjukkan bahwa harga yang ditawarkan oleh jiwasraya sudah sesuai dengan persepsi konsumen terhadap harga produk jiwasraya, sehingga dari hasil quest diperoleh nilai indeks yang masuk dalam kategori tinggi. Nilai tertinggi ditunjukkan pada indikator harga premi sesuai dengan kualitas $(6,996)$ yang berarti harga yang dibayarkan nasabah dari produk asuransi jiwasraya sudah sesuai dengan kualitas yang didapatkan oleh nasabah. Persepsi Harga memberikan pengaruh yang positif terhadap Kepuasan Pelanggan, maka jika persepsi Harga meningkat maka Kepuasan Pelanggan akan meningkat juga begitupula sebaliknya. Hasill penelitian yang dilakukan oleh Yuniati (2016) dan Suwandi, dkk (2015) mendukung penelitian ini dengan menunjukkan bahwa Persepsi Harga berpengaruh positif dan signifikan terhadap Kepuasan Pelanggan.

\section{Pengaruh Kepercayaan terhadap Kepuasan Pelanggan.}

Berdasarkan dari penelitian yang dilakukan menunjukkan bahwa menurut nasabah kepercayaan terhadap oleh PT. Asuransi Jiwasraya Kudus termasuk dengan kategori tinggi (dengan nilai rata - rata 6,527). Dapat di artikan bahwa kepercayaan nasabah akan mempengaruhi kepuasan konsumen terhadap produk itu sendiri. Hal ini ditunjukkan oleh data yang diperoleh dari penelitian dengan rata - rata indeks 6,527 menunjukkan bahwa kepercayaan yang dibangun oleh jiwasraya sudah sesuai dengan apa yang diharapkan oleh konsumen terhadap pelayanan jiwasraya, sehingga dari hasil quest diperoleh nilai indeks yang masuk dalam kategori tinggi. Persepsi Kepecayaan memberikan pengaruh yang positif terhadap Kepuasan Pelanggan, maka jika persepsi Kepercayaan meningkat maka Kepuasan Pelanggan akan meningkat juga begitupula sebaliknya. Hasill penelitian ini didukung oleh Sari dan Kustijana (2012) menunjukkan bahwa Kepercayaan berpengaruh positif dan signifikan terhadap Kepuasan Pelanggan.

\section{SIMPULAN}

Kualitas Produk menjadi variabel terbesar yang berpengaruh terhadap kepuasan pelanggan. Persepsi Harga menjadi variabel kedua yang berpengaruh terhadap kepuasan pelanggan. Kepercayaan menjadi variabel terkecil yang berpengaruh terhadap kepuasan pelanggan.

Perusahaan diharapkan mampu memiliki produk yang beragam, salah satunya adalah asuransi kesehatan anak, karena jiwasraya hanya memiliki asuransi pendidikan anak saja. Perusahaan dapat memberikan harga yang konsisten dan sesuai dengan apa yang nasabah dapatkan atau dengan cara menawarkan paket asuransi agar dapat menekan biaya yang harus dikeluarkan. Agen asuransi dirasa perlu untuk menerka asuransi yang dibutuhkan para nasabah. misalnya apabila nasabah adalah seorang mahasiswa, maka tidak perlu ditawarkan program pendidikan karena tidak akan terpakai dan hanya akan menghabiskan biaya. Lebih baik mahasiswa ditawarkan asuransi kesehatan, jiwa, atau asuransi hari tua yang akan lebih berguna di masa yang akan datang. 


\section{DAFTAR PUSTAKA}

Andesra, Yuli. 2016. Peran Kualitas Pelayanan Dalam Mebangun Kepercayaan Dan Loyalitas Nasabah Bank Syariah Mandiri Cabang Simpang Empat. Jurnal Apresiasi Ekonomi. 4 (2): 139-150.

Asie, Christin Arie. 2014. Analisis Kualitas Pelayanan Dan Tingkat Kepuasan Terhadap Loyalitas Nasabah Pada PT. Bank Pembangunan Daerah Kalimantan Tengah (Bank Kalteng) Cabang Kasongan. Jurnal Sains Manajemen. 3 (1): 75-86.

Cannon, Joseph P., William D. Perreault Jr. dan Jerome McCarthy. 2008. Alih Bahasa : Diana Angelica dan Ria Cahyani. Pemasaran Dasar-Dasar : Pendekatan Manajerial Global. Jakarta: Salemba Empat.

Daryanto. 2013. Sari Kuliah Manajemen Pemasaran. Bandung: PT. Sarana Tutorial Nurani Sejahtera

Edu. 2016. Macam-Macam Asuransi yang ada di Indonesia. http://www.mag.co.id/macammacam-asuransi-di-indonesia/

Endarwita. 2013. Pengaruh Kualitas Produk Dan Kualitas Pelayanan Terhadap Kepuasan Dan Loyalitas Nasabah Tabungan Bank BRI Cabang Simpang Empat. Jurnal Apresiasi Ekonomi. 1 (3): 167-180.

Fadillah, Rizky Yudha dan Tri Yuniati. 2016. Pengaruh Bauran Pemasaran Dan Kualitas Jasa Terhadap Kepuasan Konsumen. Jurnal Ilmu dan Riset Pemasaran. 5 (5): 1-17.

Fasochah dan Harnoto. 2013. Analisis Pengaruh Kepercayaan Dan Kualitas Layanan Terhadap Loyalitas Pelanggan Dengan Kepuasan Konsumen Sebagai Variabel Mediasi (Studi Pada RS Darul Istiqomah Kaliwungu Kendal). Jurnal Ekonomi Manajemen Akuntansi. 34: 23.

Gultom, Dedek K., Paham Ginting, Beby, KF Sembiring. 2014. Pengaruh Bauran Pemasaran Jasa Dan Kualitas Pelayanan Terhadap Kepuasan Mahasiswa Program Studi Manajemen Fakultas Ekonomi Universitas Muhammadiyah Sumatera Utara. Jurnal Manajemen \& Bisnis. 14 (01): 21-33.

Hapsari, Desty Dianti dan Imroatul Khasanah. 2012. Analisis Faktor-Faktor yang Mempengaruhi Kepuasan Pelanggan Produk Telkom Speedy di Wilayah Kota Semarang. Diponegoro Journal Of Management. 1 (1) : 1-15.

Iriandini, Anggita Putri, Edy Yulianto dan M. Kholid Mawardi. 2015. Pengaruh Customer Relationship Management (CRM) Terhadap Kepuasan Pelanggan Dan Loyalitas Pelanggan (Survey Pada Pelanggan PT. Gemilang Libra Logistics, Kota Surabaya). Jurnal Administrasi Bisnis (JAB). 23 (2): 1-8.

Kotler, Philip dan Gary Amstrong. 2008. Prinsip-Prinsip Pemasaran. Jilid 1. Jakarta: Erlangga.

Kotler, Philip dan Kevin Lane Keller. 2009. Manajemen Pemasaran. Jakarta: PT. Indeks.

Laksana, Fajar. 2008. Manajemen Pemasasaran : Pendekatan Praktis. Yogyakarta: Graha Ilmu.

Lovelock, Christopher H. dan Lauren K. Wright. 2007. Manajemen Pemasaran Jasa. Jakarta: Indeks.

Lovelock, Christopher H, Joachen Wirtz dan Jacky Mussry. 2010. Pemasaran Jasa : Manusia, Teknologi, Strategi. Perspektif Indonesia. Jakarta: Erlangga.

Mahendrayani, Ni Wayan Ita. 2016. Pengaruh Kualitas Layanan terhadap Kepuasan Pelanggan dengan Kepercayaan sebagai Variabel Intervening (Studi pada Pelanggan Lion Air di Bandara Juanda Surabaya). Jurnal Ilmu Manajemen. 4 (3).

Ningtyas, Fitri dan Basuki Rachmad. 2011. Pengaruh Kepercayaan, Komitmen, Komunikasi, Penanganan Masalah Dan Kepuasan Nasabah Terhadap Loyalitas Nasabah Bank Muamalat Di Surabaya. Journal of Business and Banking. 1 (1): 51-60. 
Vernando Satria Wijaya dan Yohan Wismantoro : Pengaruh Kualitas Produk Dan Persepsi Harga Terhadap Kepuasan Nasabah Melalui Kepercayaan Nasabah Asuransi Jiwasraya Cabang Kudus

Peter, J. Paul dan Jerry C. Olson. 2013. Perilaku Konsumen dan Strategi Pemasaran. Jakarta: Salemba Empat.

Peter, J. Paul dan Jerry C. Olson. 2014. Perilaku Konsumen dan Strategi Pemasaran. Jakarta: Salemba Empat.

Pratama, Wahyu Aditya, Andi Sularso dan Ketut Indraningrat. 2014. Pengaruh Bauran Pemasaran Jasa Terhadap Loyalitas Konsumen pada AJB BUMIPUTERA 1912 Cabang Jember. Jurnal Ilmiah: 1-4.

Pratiwi, Ni Putu Lenny dan Ni Ketut Seminari. 2015. Pengaruh Kualitas Pelayanan, Kepercayaan Dan Nilai Nasabah Terhadap Kepuasan Nasabah. Jurnal Manajemen Unud. 4 (5) : 1422-1433.

Ratnasari, Ririn Tri dan Mastuti Aksa. 2011. Manajemen Pemasaran Jasa. Bogor: Ghalia Indonesia.

Sari, Farah Mutia dan Dwi Hastjarja Kustijana B. 2012. Pengaruh Persepsi Kualitas Produk, Persepsi Kualitas Pelayanan Dan Trust Pada Kepuasan Konsumen Di Perusahaan Taksi PT. Kosti Solo. Jurnal Fokus Manajerial. 11 (2): 183-194.

Siregar, Syofian. 2013. Metode Penelitian Kuantitatif : Dilengkapi Perhitungan Manual \& SPSS. Jakarta: Kencana Prenada Media Group.

Soedijati, Elisabeth Koes. 2011. Pengaruh Bauran Pemasaran Perguruan Tinggi terhadap Kepuasan dan Dampaknya pada Loyalitas Mahasiswa pada Tiga PTS Terkemuka di Kota Bandung. Jurnal Bina Ekonomi. 15(2): 94-106.

Solechah dan Euis Soliha. 2015. Pengaruh Citra Dan Kepercayaan Terhadap Nilai Pelanggan Dan Dampaknya Pada Kepuasan Serta Loyalitas Nasabah. 4th Economics \& Business Research Festival: 401-410.

Sugiyono. 2012. Metode Penelitian Bisnis. Bandung: Alfabeta.

Suratman, Andriyastuti. 2015. Analisis Pengaruh Perceived Value, Kepuasan Dan Kepercayaan Pada Loyalitas Konsumen (Studi Pada Pelanggan Transportasi Rosalia Indah, Karanganyar). Jurnal Bisnis dan Ekonomi Efektif. 6 (2): 25-38.

Suwandi, Andi Sularso \& Imam Suroso. 2015. Pengaruh Kualitas Layanan, Harga Dan Citra Merek Terhadap Kepuasan Dan Loyalitas Pelanggan Pos Ekspres Di Kantor Pos Bondowoso Dan Situbondo. Jurnal Ekonomi Akutansi dan Manajemen (JEAM). :68 88.

Tjiptono, Fandy. 2008. Strategi Pemasaran. Yogyakarta: Andi.

2011. Pemasaran Jasa. Yogyakarta: Bayumedia Publishing.

Umar, Husein. 2013. Metode Penelitian untuk Skripsi dan Tesis Bisnis. Jakarta: PT. Raja Grafindo Persada.

Undang-Undang No. 2 Th 1992. Tentang Asuransi. 